\title{
Consonance as an Expression of Artistic Expression in the Modern Lyrical Genre
}

\author{
Mirzayev H.A. \\ Faculty of Engineering Business and Management \\ Department of Azerbaijani Language and Pedagogy \\ Azerbaijan Technical University \\ Baku, Azerbaijan
}

\begin{abstract}
In this study, the consonance observed in the lyrical genre are considered as expressions of art and are highlighted in different ways. The coverage of this issue on the basis of the works of the well-known Azerbaijani writer H. Arif is of particular relevance. The main purpose of the research is to identify new sounds undertones and rhythmic features of consonance in the lyrical genre. For this purpose, it is intended to use a descriptive method during the study. Analysis of consonance in the lyrical genre based on the poetic texts of the modern Azerbaijani language constitutes the scientific novelty of the article. During the research, it is concluded that assonance and alliteration are the product of aesthetic and architectural creativity of the word artist. Both events are mainly accompanied by pronunciation and intonation.
\end{abstract}

Keywords-consonance; lyrical genre; H. Arif; identify of sounds; poetic texts; Azerbaijani language.

\section{INTRODUCTION}

"The cultural memory of the language" [1:51] resides in the literary language of each nation, especially in its poetry. Different methods and means are used in his poetry, in particular the specifics of each language, among which consonance are of particular interest. Although there have been many studies in linguistic literature on vocal reproduction, the new combinations we find in poetic texts make this issue relevant. The purpose of our research is to examine and analyze the artistic ability and capabilities of consonance in the lyric genre in the expression of $\mathrm{H}$. Arif. For this purpose, we aim at referring to descriptive metadata in the study.

Listeners are sensitive to intonational structure in their perception of segmental contrasts [2]. For the first time, the study of sound repetitions in the lyrical genre based on the materials of the modern Azerbaijani language, based on the creativity of $\mathrm{H}$. Arif, promotes the scientific novelty of the article.

Depending on the style, $\mathrm{H}$. Arif creates sound situations with the repetition of different phonemes, along with the musical features of different words, expressions and sentences. To do this, they use specific sounds, purposeful vocalizations, and even mimic words and sounds.
For the first time, the study of consonance in the lyrical genre based on the materials of the modern Azerbaijani language, based on the creativity of $\mathrm{H}$. Arif, promotes the scientific novelty of the article.

Depending on the style, $\mathrm{H}$. Arif creates sound situations with the repetition of different phonemes, along with the musical features of different words, expressions and sentences. To do this, they use specific sounds, purposeful vocalizations, and even imitative words and interjections. In such situations, the style of ordinary sounds becomes a tool, as well as artistic materials.

\section{RESEARCH METHODOLOGY}

In the lyrics of $\mathrm{H}$. Arif, the expressive potential of the national language is characterized by a stronger style at the phonetic level. The sound and intonation traditions of our poetry, and the spiritual power nourished by these traditions, demonstrate all the possibilities. All of the artistic soundtracks in his pencil are at the same time a powerful aesthetic touch. Phonetic instruments are very active in the formation of sounds in the hemistich, the rhythmic syllables, and the completeness of the intonation sequence. It is not unusual for H. Arif's style to recite poetic lines with identical phonetic units in order to emotionally capture the literary text. The rhythmic flow of thoughts and feelings is of particular importance in phonetic parallelism and sound repetitions, "creating maximum alignment between form and content" [3: 930].

One of the important features of H. Arif's poetic language is the concurrence and parallels of the assonance with alliterations in the same hemistich. The abundance of assonance and alliteration is seen as one of the most striking signs of poetry in his works. One of the most striking signs of in H. Arif's language personal style is the perfection of the alliteration and assonance style. The balance of assonance and alliteration is a very important factor in the poetry of $\mathrm{H}$. Arif's lyrics, and they play an instrumental role in creating intonation, rhythm, and acoustics of hemistich, as well as in the formation of an artistic atmosphere and the arrangement of pronunciation.

The most important thing is that repetition of vowel and consonant sounds in the same text corresponds to the content 
of the poem, the literary text, and the main directions of the poet's personal style.

The lyrical content is caused by the agonizing intonation created by assonance and alliteration. Creation of harmonious syllable waves and its adaptation to the psychological conditions in the poem are of assonance and alliteration method. For light-flexible intonation shades and pronunciation dynamics, alliteration and assonance are the main textual stimulus:

Yolu, izi payız kəsir,

$q, l$ Qapımızı qış alıbdı. [4: 31]

$l, a, u$ Misralar alovlu, duyğular ulu

$y, a$ Nə yaman yanmısan, yanan könlümə

Bir xalqa dağ çəkdi bir şair oğlu

$m, a$ Aman haraylaram aman könlümə. [4: 42]

The aesthetic value of alliteration and assonance is facilitated by the easy perception of the content embodied in the form and structure of the poem. This requires the artist to create a charm with his specific choice of language materials. The principles of expression, such as simplicity, compactness and expressiveness are main to the sound and word composition

One of the most important features of the poem is the connection between the rhythm and intonation to inside of the text created by alliteration and assonance. The flow of speech is easily divided into rhythmic sections, and sintagm are noted by means of appropriate sound similarities as rhythmic units. "It is well known that events and processes do not occur in isolation, but, as a result of interaction and influence, make our modern poetry enriched in terms of language and expression, to better reflect the realities of modern life, the spiritual world of the modern man" [5: 193]. Such a principle plays a major role in the style of poetry of $\mathrm{H}$. Arif. The most reliable particles are in harmony with the largest language units. Sounds, sounds melodies are active participants as artistic factors along with words, word combinations, sentence structures, and form relationships between content and form. Attention to the language factor serves to express the content and idea of $\mathrm{H}$. Arif in original forms. Therefore, there are virtually no expressions, incomplete images that do not sound right with the works of art from his pen. It is impossible to find poetry patterns that are below the level of mastery due to the language excellence.

In the lyrical genre, phonemes can easily express their expressions through alliteration and assonance. Possibilities of harmony and fluidity are the main means for the formation of rhythmic groups in the dividing groups of hemistich. It doesn't cause systematic and casual in the language of lyric poets like H. Arif. This permanent character is associated with features of the lyrical genre, realizes mental and emotional content, and contributes to the linguistic reflection and perfect expression of poetic thinking. The main method of alliteration and assonance is the artistic method of artistic language, especially in the poetic speech.

\section{RESULTS}

The expression of lyrical excitement, lyrical impressions in compact and laconic, emotional and expressive forms appear as the internal contact of alliterations and other methods of assonance. The music, flow, and harmony in H. Arif's poetry are primarily responsible for the symmetric sound quality that arises from the repetition of sounds. Speaking of his literary language culture, along with the obvious style and poetic factors, it is necessary to take into account the experience of creating aesthetic beauty in the poet's creativity as a distinct set of lines. Alliteration and assonance are sung by H. Arif's poem because of consonance as an artistic need for their style. Because of the specific texts creation, the artistic thought is accompanied by emotion. Alliterations and assonances that accompany the language of the text carry a particular poetic weight. Thus, sound figures are quite suitable for the poetic language:

$u, \ddot{u}, l$ Üfüqlə uzanıb, buludla axıb,

ş, ç, ə Şəfəqlə qızarıb, şimşəklə çaxıb

$l, b, a$ Cüyürlə boylanıb, maralla baxıb

$y, l, b \quad$ Ceyranla yorulub yatmaq istərəm. [4: 192]

a Forhad kimi qaya çapıb, daş yaran,

$s ̧, u \quad$ Şux oturub, şux yeriyib, şux duran,

$d \quad$ Bəd ayaqda qoldan tutub qaldiran,

Böyükləri, ucaları varıydı. [4: 1690]

Alliteration and assonance, in addition to the beauty of poetry, are poetic in nature as a source of rhythm and intonation. It plays an exceptional role in the rhythmic pronunciation of the hemistich, intensifying the internal dynamics of the artistic content, giving it a moving character. The direct result of this is that "the communicative function of the language acquires the function of artistic expression" [6: 411]. This is also the poet's expressive attitude and is the main content of the poetry's beauty of form. The beauty of the form, the inner content of the poem, the hidden poetic passages, the magical essence attracts the reader more. The harmony created by the hemistich has its new style of limits, with its distinctive poetic tones presenting a rich lyrical structure. H. Arif's serious and widespread emphasis on phonological figures is also due to the active, leading role of alliteration and assonance in his style.

ç, ş - Çox şey əriyəcək...Çox şey dünyada,

$d, a$ - Dəmir də, polad da, daş da, qaya da

$b, i$ - Bir q1ş öz hökmünü dəyişən deyil,

$b, i$ - Bir payı, bir bahar, bir yay, bir də mən. [4: 101] Hüseyn Arif, daha nə qəm,

ə, $d, i$ - Oldə qələm, dildə Dilqəm Unudulsa Yaniq Kərəm

Nəsillərə haram olsun. [4: 2004]

The style of expression involving the assonance and alliteration is not simply a pleasant impression. Behind this form of expression stands the whole concept of figurative perception. The basic features of reality lyrical perception, the lyrical excitement and the expressiveness of judgments, and the harmony created by phonetic units for poetic confirmation of thoughts and emotions are quite effective in H. Arif's 
Assonance and alliteration, transforming sounds into poetic means of stimulating the rhythmic organization of artistic speech, lay the foundation for emotional speech. "Expressive discourse interpretation is an active, creative and highly conscious activity, producing cognitive effects which are irreducible to the propositional meaning of the utterance, to the inferential process" [8: 192]. As it is known, tension develops in parallel with the content of the mind, emotion is needed for consonance, because "emotion is the soul of repetition" [9: 148]. Examples of poetry by H. Arif show that there is a certain standard and requirement for the use of identical sounds that are arranged according to the meaning of the text to evoke emotion. Assonance and alliteration can reflect the pronunciation and harmony of our language. Their harmony determines the regular arrangement of the hemistich.
ə, $d$ - Ozizlədi dönə-dönə
Dönüb yenə əzizlərəm
$y$ - Yönü bəri düşər deyə
ə, z - Yolu, izi təmizlərəm. [4: 64]
$d$ - Dağıtmaq istərəm dumanı, çəni
$o, y$ - Oyanıb o başdan bahar yeliylə
$z, i$ - Dağların zirvəsi gözləyir məni
$a, \breve{g}$ - Ağrıma, ürəyim, ağrıma hələ. [4: 140]

As it turns out, H. Arif's poetic thinking and his poetry are characteristic of a perfect sound system and artistic texture based on a harmonious structure. In his poetry, the means of phonological expression enter into various relations with other linguistic materials, thus, in the context of the connection to the artistic system, the assonances and alliteration take an active part in the creation of original verses and clauses. Assonance and alliteration including to the poetic elements serve to the diversity of artistic and logical relationships. Within a compact poetic system, consonance is based on the artistic content of many forms. The phonological repetition acts as a topical typological factor in the "transfer of language to cultural memory" [1: 51] expressing moral values and structuring the appearance of the text. The phonological language factor is particularly important as assonance and alliteration as a rhythmic stimulus in the syllabic metre system. Vowel harmony and alliterativeness determine the phonopoetic nature of the poem. It is clear from the experience of $\mathrm{H}$. Arif's style that assonance and alliterativeness are not only thought of as formal signs, but these formal signs are closely linked to the poetic semantics of the poem. The structural-semantic completeness of H. Arif's poem is that the unity of the poetic content with the formal elements plays the role of the artistic perfectionist.

These qualities in H. Arif's poetic system are tied to the individual artistic thinking. Poetic perception is based on the conscious repetition of certain phonetic units. The textual functionality of the same voice is quite affordable in terms of style and activity in the system of artistic description and expressions. That is why the form in the poetry of $\mathrm{H}$. Arif is essentially indistinguishable from the content. This means that all the means of expression of $\mathrm{H}$. Arif's poem are closely related to other elements of the poetic system, especially the phonopoietic elements. 
$m, n, i$ - Mən daha nə deyim, ay Mingəçevir,

$s ̧, a, i$ - Sağ əlin Şəmkirin başına olsun! [10: 38]

$y, a, s ̧$ - Yaş ötdü, yaşayan yaşıdlarım az,

Gecələr çən-çiskin, gündüzlər ayaz.

$d, o$ - Dediyim o şeir, aldığım o saz

$a, c$ - Ağrıdan-acıdan bac almağımdır. [10: 512]

Assonance and alliteration gave $\mathrm{H}$. Arif poetry the light of the Ashug Alasgar poem creativity. The outward harmony of the sound lines stretches as wave, creating an original poetic climate in the text. The original form of the content as a poetic echo touches the reader's heart. It maintains the folklore color that accompanies the alliteration with assonance and brings the poet's style closer to the oral folk literature. Repetitive sounds are such a component of the poetic text that its successful use reveals the aesthetics of the literary language. Consonance is not simply the processing of the same phonetic units at close distances. H. Arif's poetic experience confirms that both assonance and alliteration are the product of aesthetic and architectural creativity of the word artist and are accompanied by pronunciation and intonation. This sense is even more pronounced by the vowel sounds in hemistich or in whole verse clauses consisting only of front or back vowels in words. As an example:

Çiçəklər incəlik, güllər zəriflik,

a, $i$ - Sünbüllər bərəkət gətirir bizə.

$d, r, \partial, i$ - Dərələr dərinlik, düzlər genişlik

$z$, - Zirvələr əzəmət gətirir bizə. [10: 87].

\section{CONCLUSIONS}

It is interesting that repetitions connect with poetic moods, reviving the aesthetic character. The repetition of each type of vowel sounds gives the impression of a natural pattern, and the poet enjoys them as a science that implements these patterns. The use of alliteration along with the assonance gives the poetic language emotional and expressive features.

The content is complemented by the mature pronunciation flow of sound repetitions and thus lyrical detail emerges. Language sensitivity crosses the poetic semantics that carry lyrical burdens with poetic elasticity. With the transfer of ordinary sounds to exemplary poetic speech paints, the author seeks to formulate a particular expression system.

\section{References} intonation adaptation, increasing the frequency of lexical units close to the phonetic volume. The repetition of the same monotonous phonetic units and the density of the same and close hemistich creates a poetic-style color harmony, and the repetition construction exaggerate the tone of the poem and the perfect tone of poetry in hemistiches. Thus, both the assonance and the alliteration give rise to the language-style roots, the intensity of the poetic process of the text, as the individual details exhort the poet's personal creativity, and serve as a poetic plot that combines the lyrical undertones. All of these factors are aimed at enhancing readers' memory and enriching their artistic taste:

$s, v-$ Sürət işıq sevir, sərvət su sevir, Kürün yaxasında göllər durulsun.
[1] Churillina, L.N. Antropocentrizm hudezhestvennogo teksta kak princip organizacii ego leksicheskoj struktury. Saint-Petersburg. 2003.

[2] Steffman, J. Intonational structure mediates speech rate normalization in the perception of segmental categories. Journal of phonetics. 2019, vol. 74, pp. 114-129, DOI: 10.1016/j.wocn.2019.03.002

[3] Khalilzadeh, A. Vowel harmony: A comparative study of Turkey's and Azerbaijani Turkish. Akdeniz Language Studies Conference. 2019, vol. 70, pp. 929-935. DOI: 10.1016/j.sbspro.2013.01.140

[4] Huseyn, A. Seçilmiş əsərləri. Bak1, "Şərq-Qərb". 2004, 224.

[5] Abbasov, İ. Müasir Azərbaycan poeziyasında işlənən fellərin bəzi linqvopoetik xüsusiyyətləri (Xalq şairi Məmməd Arazın yaradıcılığı üzrə). Pedaqoji Universitet Xəbərləri. Bak1. 2013, 4, pp. 189-193.

[6] Nazarenko, V.A.Yazyk iskusstva. O masterstve poeta i prozaika. Leningrad. 1961, 506

[7] Jirmunsky, V.M. Teoriya stikha. Leningrad. 1975, 664. 
[9] Timofeev, L.İ. Slovo o stikhe. Moscow. 1978, 424.

[8] Longhitano, S. Communicating the ineffable. A pragmatic account of literariness. Procedia Social and Behavioral Sciences, vol. 158, 14th Language, Literature and Stylistics Symposium. Selcuk, TURKEY. 2014, pp. 187-193. DOI: 10.1016/j.sbspro.2014.12.068.

[10] Huseyn Arif. Seçilmiş əsərləri. Bakı, "Şərq-Qərb". 2011, 264.

[11] Qafarova, S. Azərbaycan xalq șeirində bədii üslub. Bakı, Mütərcim. 2006, 156. 